\title{
Application of Films and TV Programs in English Literary Works
}

\author{
Lei Ming \\ Xi'an International University, Xi'an, Shaanxi Province, 710077 \\ 441752855@qq.com
}

\begin{abstract}
Key words: English films and TV programs, English language literature, innovation of English teaching
\end{abstract}

\begin{abstract}
With the deepening of China's reform and opening-up, learning English has become more and more important in our life. With the development and improvement of science and technology, college English teaching also becomes more and more diversified. So with the wide application of multi-media, the combination of English teaching and films and TV programs has become a typical way of teaching mode. Applying authentic films and TV programs in English teaching has become a new language teaching mode. Because of the wide application of films and TV programs in English literary works, students can experience the culture of foreign culture so that teachers will study and make full of them in teaching.
\end{abstract}

\section{Introduction}

Linguistics English is a professional course designed for students majoring in English literature. It is also an important preliminary compulsory course. Mastering linguistics English enables us to learn theories and concepts about linguistics well and systematically and finally promotes the competence of researching language so that we can have a quick command of English as a foreign language. This course aims to strengthencollege students' competence of learning English, systematically learn modern linguistics culture, systematically compulsory course required and improve students' creativity.

Linguistics English is a secondary brand of foreign linguistics, so in order to know about it, we need to get to know the development and characteristics of foreign linguistics. Foreign linguistics belongs to the first branch of arts, and it contains many secondary branches. It consists of English, Russian, German, French, Japanese, Indian language and languages of Asian countries and African countries. We need to learn to listen, watch, writing and reading, translation theories and practice, linguistic theories, newspapers selections, the national situation of related countries and literary works, etc. while the major of foreign languages mainly focuses on language research which consists of lexicology, grammar, phonetics, linguistics and comparative linguistics.

Applied linguistics has its own definition both broadly and narrowly. In its narrow sense, it explores the teaching of the second foreign language and foreign linguistics. In its broad sense, it refers to the combination of languageand computer, language and government policies, unification of human intelligence and language, combination of language and other subjects.

\section{Teaching Innovation and Reform}

While learning college English, students mainly focus on acquiring and storing knowledge. With a certain accumulation, students will transform them into their own knowledge and ability after their hard work of practice and imitation. Therefore, teachers' teaching is inevitable. Through 
teaching, students can acquire knowledge and store so as to master this strategy. A set of systematical linguistic theories and a knowledgeable and experienced teacher are important factors to ensure that high-quality students will be cultivated. With the guidance of scientific linguistic theory and knowledge of linguistics, the diversity and rationality of language teaching will be achieved through language teaching.

There are some problems existing in linguistics English in teaching. That is the fact that teachers always teach only based on textbooks. At the very beginning, when students get to learn a new language, they only acquire some theoretical and abstract knowledge through textbooks, so the teaching is too simplified and the effect is very poor, which can not attract students' interest to learn. It is scientifically shown that nowadays, there still exist the problem that in many places, linguistics teaching still focuses on the spreading of linguistic theoretical knowledge. It can not be applied to practice, which finally influenced the teaching quality. Besides, in some schools, English has become the NO.1 course which many students can not pass. One the one hand, linguistics is too professional, so students feel bored and dull to learn. For example, the professional terminologies are too difficult to memorize. And many people think they are useless.

As for beginners, linguistics English is too abstract, so it's very difficult to learn and students feel bored. Therefore, teachers need to lead and guide students in the first hand to cultivate their interest in learning and hunger for knowledge so that they can love this subject. So this demands teachers' hard work and their patient explanation to apply theories to practice, then use some techniques to achieve the best teaching effect. Only by doing so, students can feel interested and learn linguistic knowledge. According to the survey questionnaire, more than $40 \%$ students believes that learning linguistics English is dull and boring so that they are reluctant to learn the subject. Therefore, more interesting activities and flexible teaching strategies are needed in class. For example, dialogues, short play, appreciation of authentic films, interesting questions and answers, etc are encouraged. As for linguistics English, teachers reduce the professional terminologies and abstract concepts and explain in very simple sentences in class so that students can better understand and master those culture and knowledge. This will not only increase students' love for linguistics English but also realize the value of linguistic knowledge in practice, which makes it more realistic.

In English teaching, all the research projects and textbooks are English, and most of them are explained in English as well. Although it can improve students' spoken English, it indeed has too many professional terminologies which are too difficult to understand. So it is necessary to explain some terminologies and concepts in Chinese so that students could have a better understanding. Owing to the cultural differences between China and the West, it needs more bilingual teaching, through the further explanation and exemplification, students will deepen their understanding about linguistics English. Besides, it can cultivate students' awareness of the cultural differences.

Owing to the development of science and technology, classroom teaching has a new way. Nowadays, it is not unusual to make use of multi-media teaching because PPT is a good aid to teachers. It is also very obvious that making use of modern technology in teaching has a lot of advantages. It can not only ensure the increase of large group of information but also improve teaching efficiency. Besides, it's also very easy to understand because it help teachers make the abstract concepts and professional knowledge easier and more simplified. On the other hand, there's a huge amount of teaching materials on the Internet, which helps teachers have deeper understanding of languages because it also serves a very important communication platform for teachers and students. 


\section{Research and Application of Films and TV Programs in English Language Literature}

With the development of society and the deepening of reform and opening up, more and more people begin to use English, which requires us not only to use English, more importantly to speak English so as to apply the theories of linguistics English to our life. However, traditional textbooks learning can not meet the demand of new times, so applying the application of films and TV programs in English culture has become a new language teaching mode and it has been studied by English teachers. Then, more and more students love learning English by watching films and TV programs. This will exert profound influence on English teaching. The application of films and TV programs in teaching English will essentially solve the problem of traditional teaching. Besides, it can cultivate students' language sense and context. So this paper will focus on analyzing the profound impact of authentic films and TV programs on English literary works and its practical function.

Firstly, authentic filmshave been applied to English teaching. Traditional linguistics literature expresses through words and they are indirect with arts. So people need to be more creative while learning. They need to transform every word into vivid and motional pictures. So traditional linguistics English is abstract, and learners have little interest in learning. Through visual pictures of films and TV programs, students can learn directly which helps them learn English exactly and effectively. Except for subtitles, students also learn English well by sound, pictures, context and performances, which inspires students great interest and love for linguistics English. What's more, through classroom learning and reading, students will have deeper understanding of linguistics English so as to achieve vivid expression of linguistics English. Secondly, through films and TV programs, students can strengthen their understanding of western history and culture. As for learning linguistics English, we need not only to lead students' interest and love but also to allow students know background knowledge and history. Films and TV programs are embodiment of social life and historical culture of a country and democracy, which reflects real life of westerners. Through films and TV programs, students can learn the history, politics, geography and economy of western culture directly and they are easily expressed and understood. Only with right guidance and proper application, students can learn western culture unconsciously. For example, students can understand life and life through Friends, connotation and spirit of American culture in Forrest Gump. All those films and TV programs can help students directly learn the culture and history of western countries by which students will be attracted to get to know western history.

Because films and TV programs can create good atmosphere of linguistics English, so students' fire in learning English are inspired to a large extent. In English teaching, it is necessary to apply films and TV programs to practical teaching. It not only improves students’ listening and speaking ability, but also provides a window for students to learn western culture and history so that they can achieve a win-win in language culture learning. Firstly, it can improve students' learning efficiency. Traditional linguistics English is too complicated and abstract, so it's not realistic to learn more knowledge within certain time through textbooks. However, after-class learning lacks of teachers' tutoring and explanation, so it will be much more difficult to learn. While films and TV programs can reflect exact language information, fully inspire students' fire. Through motional pictures and dialogues, students can improve their spoken English, learn some English expressions and improve their memory so as to improve their learning efficiency. Secondly, it can improve students' spoken English. Films and TV programs are motional media. It can reproduce the language communicative situation in whichstudents can acquire a large number of authentic English language to deepen their understanding of spoken English. It will help create forceful language environment and atmosphere and lay a solid foundation for the English teaching effect. Students can learn by imitating to correct 
and improve their spoken English. As a result, they can have a good command of English and speak English fluently. Thirdly, it can motivate students'interest in learning English. Films and TV programs contain a wide area of various contents. After actors' performance, they can be deeply love by audiences. Through strong English appeal, English language learning has become an enjoyment. It can improve students' confidence and inspire their interest in linguistics and hunger for knowledge. Fourthly, it is conducive to the spreading of western culture. While learning English language, students not only learn the grammar and vocabularies but also the culture and history. Films and TV programs can show and express the social culture and history through art form so as to vividly and directly show the historical events, social customs and cultural atmosphere. Therefore, films and TV programs are important medium for English language teaching.

\section{Conclusion}

In this global age, mastering English becomes more and more important. English literary works not only help people learn English, but also learn more about its historical background so as to learn English quickly and effectively. This paper highlights the advantages and features of films and TV programs by introducing the application of films and TV programs in English literary works in order to inspire students' fire and passion for learning English. What's more, this paper aims to highlights the importance and advantages of films and TV programs in English teaching.

\section{References}

[1] Fu Lei. Biography of Fu's Translation[M]. Bei Jing: The Joint Publishing Company Ltd, 1996

[2] Fu Lei, Fu Min. Roman Rolland Masterpieces Set[M]. Henan People’s Publishing House, 1998

[3] Ge Baoquan, Roman Rolland. John Christophe[M]. Reading and Publishing, 1946

[4]Krashen S. 1985. The Input Hypothesis: Issues and Impac-tions[M]. Longman.

[5] Zhang Jing. On English Films and College English Listening and Speaking[J]. Reform of Teaching, 2009 